\title{
Research Seminar
}

\section{癌転移と接着分子}

\section{癌転移と接着分子}

済木 育夫*

\section{Summary}

癌の転移形成過程は癌細胞相互あるいは癌細胞と宿主の細胞（特に血管内皮細胞，免疫 系細胞や血小板など）あるいは細胞外マトリックスなどの種々の生体成分との間の複雑な 反応カスケードから成り立っており，これらの相互作用は癌細胞の転移形質の発現に重要 な役割を果たしていると考えられる。最近，多くの細胞接着に関与する分子およびその受 容体が明らかにされつつあり，その制御ならびに分子機構が注目されている。従来，細胞 外マトリックスを構成する接着分子としてフィブロネクチンおよびラミニンなどが癌の転 移と深く関係していることが示唆されてきた。私共は癌の転移とその形成過程における細 胞接着分子およびその分子との相互作用に着目し, いくつかの接着ポリペプチド(特にフィ ブロネクチン由来の細胞認識配列 RGD 関連ぺプチド）を用いて癌細胞の機能（接着性・運 動性・浸潤能など）を制御することにより，癌転移の抑止とその機序を解明しようとする 試みを行ってきた。本研究はさらに癌転移の防止あるいは治療に有効な薬剤開発の手がか りを与えるものと思われる。

\section{はじめに}

癌細胞の転移性は，その自律的な増殖ととも に悪性度を特徵づける指標であり，診断および 治療法が進んだ今日でも克服することができな い臨床上の大きな課題である。癌転移の実験モ デルが確立されて以来 ${ }^{1)}$ ，この現象を細胞レべ ルで研究することが可能となり，さらに近年で は癌転移の複雑な機序が分子レベルで解明され つつある。

本稿では，癌転移を決定する種々の因子のう ち癌細胞と細胞外マトリックスとの接着相互作 用および癌細胞の接着機能を制御することによ り癌転移の阻止を試みようとする最近の知見に ついて紹介する。

*Ikuo SAIKI : 北海道大学免疫科学研究所

\section{癌転移の機序}

癌の転移は癌細胞の原発巣からの離脱と周辺 組織への浸潤から転移組織での増殖に至る複雑 な過程を経て成立している(図 1)。また，これ らの過程は癌細胞側と宿主側の因子に影響され る。前者において, 原発巣は絶えざる遺伝子変 化に伴い, 増殖能, 薬剤感受性, 免疫原性, 形 態などの異なった細胞形質を示す不均一な細胞 集団から構成されており，高/低転移能2)，周辺 組織への浸潤能3), ある種の転移性癌細胞から の自己増殖因子の産生 ${ }^{4) な と ゙, ~}$ 種々の要因が挙 げられる。

一方，宿主側の要因としては，血中内での物 理的あるいは解剖学的条件, 免疫担当細胞によ る防御機構, 血管内皮細胞および血小板との接 着相互作用, さらに転移周辺組織からの増殖因 


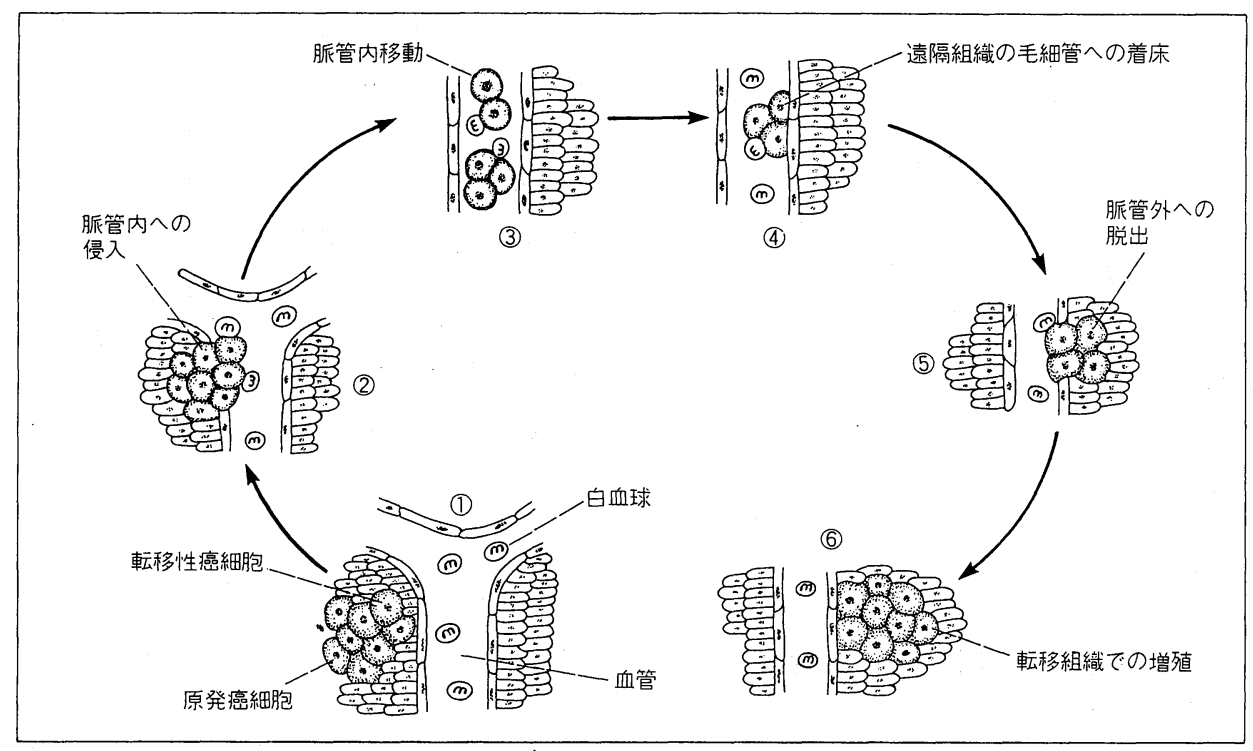

図 1. 癌の転移形成過程

子の影響5などが考えられる。

このように，癌転移は遺伝子変化により転移 に好都合な細胞形質と臓器・組織選択性を獲得 し，さらに宿主の淘汰圧から逃れ首尾よくこれ らの過程を突破した少数の癌細胞によって形成 され得るのである。

\section{細胞接着分子}

癌転移形成の一連の動きの中で, 癌細胞は宿 主の正常細胞や癌細胞同士，あるいは細胞外マ トリックスを含む種々の生体成分に影響され， 癌細胞の転移形質の発現と調節が決定されてい るものと考えられる。最近，正常あるいは癌細 胞を問わず細胞接着現象やその接着分子につい て分子レベルで解明されつつあり, 構造上の類 似性からカドへリン ${ }^{6)}$, 免疫グロブリン7)，イン テグリン778)およびセレクチン799)・ファミリーが 明らかとなってきた。これらは主として膜貫通 型タンパク質で接着を通じ細胞内への情報伝達 を介して基本的な細胞活動（接着・運動・移動・ 増殖・分化など）の調節に寄与していると考之 られる。

癌細胞同士あるいは癌細胞一正常細胞間の接
着は細胞表面に発現されている細胞間接着分子 が介在しており，カドへリン分子群，免疫グロ ブリン群あるいはセレクチン分子群などが知ら れている。一方，フィブロネクチン，ラミニン， コラーゲンなどの糖タンパク質やへパラン硫 酸，コンドロイチン硫酸などのプロテオグリカ ンを含む細胞外マトリックスと癌細胞の接着は インテグリン分子群を含む細胞表面上の接着分 子などが関与している。癌の転移における細胞一 細胞あるいは細胞一細胞外マトリックスに関わ ると思われる接着相互作用を図 2 に示す。

これら接着分子は細胞同士の分子識別, 細胞 機能調節あるいは細かな網目構造を形成するな ど，癌転移と密接に関わっている。

\section{細胞外マトリックスと癌転移}

従来, フィブロネクチンやラミニンなどの細 胞外マトリックス分子が癌の転移に深く関与し ていることが指摘されてきた。細胞が腫瘍ウイ ルスや化学発癌剤などにより悪性転換すると, 細胞外マトリックス分子，特にフィブロネクチ ンの合成や細胞外への蓄積が減少すること ${ }^{10)}$, さらに最近になってインテグリン分子 $\left(\alpha_{5} \beta_{1} レ\right.$ 


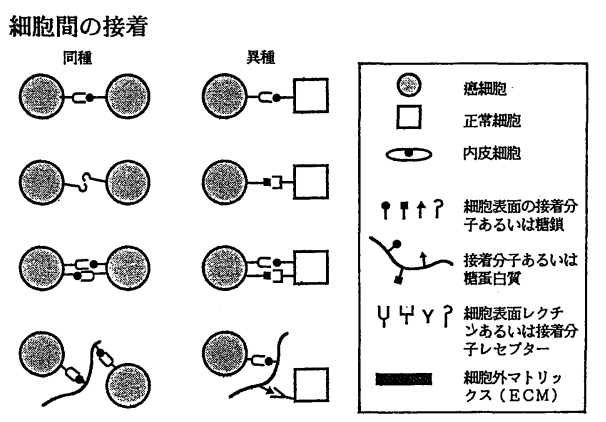

癌細胞の内皮細胞あるいは細胞外マトリッ クスへの接着

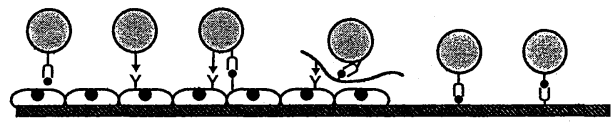

図 2.癌転移における細胞一細胞あるいは細胞一細胞外 マトリックスの接着相互作用

セプター）の発現量の減少やフィブロネクチン への接着性の低下も示された ${ }^{11)}$ 。フィブロネク チンやラミニンは癌細胞の接着, 移動能を促進 すること ${ }^{12)}$ ，転移性癌細胞では膜上のラミニン レセプターの発現が高いこと ${ }^{13)}$ ，ラミニンであ らかじめ培養した癌細胞は基底膜を構成するコ ラーゲン分解酵素を誘導し，さらに肺への転移 能が著明に増加すること年)などが報告されてい る。

フィブロネクチン（図 3 ) あるいはラミニン 分子はドメイン構造をもち分子内に多くの機能 を分散させている。生化学的あるいは遺伝子工 学的手法により構造が明らかにされるとともに 複数の細胞接着部位の存在とそれに対するレセ プターも多数発見されてきた。細胞結合ドメイ ン内の RGD 配列が細胞認識部位であり ${ }^{15)}$ ，多
くの細胞接着関連分子にも存在・機能し，その 細胞受容体が $\alpha_{5} \beta_{1}$ インテグリンレセプターで あることが同定された ${ }^{16)}$ 。最近 RGD 配列以外 にIII CS (type III homology connecting segment）領域内に CS 1 ペプチドおよび CS 5 ペプ チドが存在し，メラノーマ細胞， Tリンパ腫細 胞さらにBリンパ芽球などが選択的にこの領域

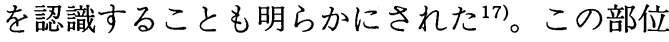
を認識する $\alpha_{4} \beta_{1}$ レセプターはサイトカインで 活性化された血管内皮細胞上の VCAM- 1 と も結合する ${ }^{18)}$ 。さらに，33KDa ヘパリン結合フ ラグメント内に細胞接着配列としてペプチド I およびII も見出されている ${ }^{19)} 。 \alpha, \beta$ 鎖からなる インテグリンレセプターは細胞外マトリックス のみならず細胞間の接着においても重要な働き を持ち, その認識機構が $\alpha, \beta$ 鎖による接着特異 性に加えて糖鎖部分により複雑に調節されてい

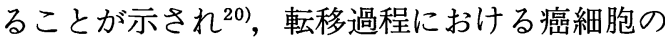
接着・遊離の制御に関与していることも予想さ れる。

一方，基底膜に固有の接着分子であるラミニ ンは，十字架様の構造を持ち，その分子内の A 鎖上に RGD 配列を有しているが，これとは別

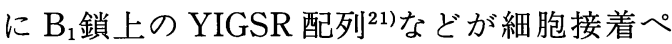
プチドとして同定されている。現在これらを認 識するレセプターの解析も進められている。

\section{細胞接着制御による癌転移抑制の試み}

細胞接着分子と細胞との接着相互作用が明ら かにされるとともにその機能を制御しようとす る試みとして, 近年, 細胞接着ぺプチドを癌の

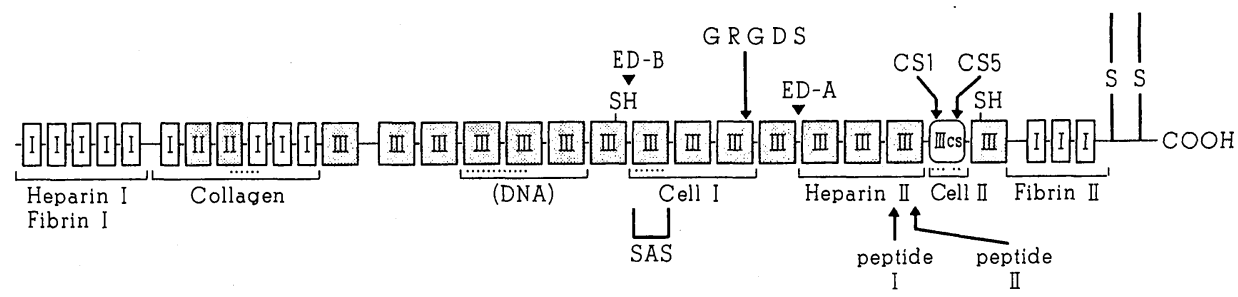

図 3.フィブロネクチンの構造と細胞接着部位 
転移抑制に応用することが可能となってきた。 Yamada ら ${ }^{22)}$ はフィブロネクチンの接着シグ ナルとしての GRGDS ペプチドが, Martin ら ${ }^{23)}$ はラミンンの接着ペプチド CDPGYIGSR や PDSGR がメラノーマ細胞 B16-F10 の肺へ の実験的転移を抑制することを示した。我々は RGD 配列を繰返し単位に持つ poly (RGD)およ びその関連ポリペプチド類を用いて癌転移の抑 止とその機序の解析を試みておりその一部を紹 介寸る ${ }^{24) ~ 31) 。 ~}$

マウスの実験的および自然肺転移モデルを用 いた合成ポリぺプチドの転移抑制効果は表 1 A およびBに示した。3 種のマウス転移性癌細胞 B16-BL 6 メラノーマ, ルイス肺癌およびコロ ン26結腸癌およびヒト A375M メラノーマ細胞 による実験的肺転移を poly (RGD) は有意に抑 制し,さらに治療実験モデルである自然肺転移
系においても同様に著明な転移抑制効果を示し た（図 4)。しかし RGD 配列をもたないランダ 厶 poly (R， G，D) では全く抑制効果が認めら れない。Poly (RGD) による癌転移抑制機序に

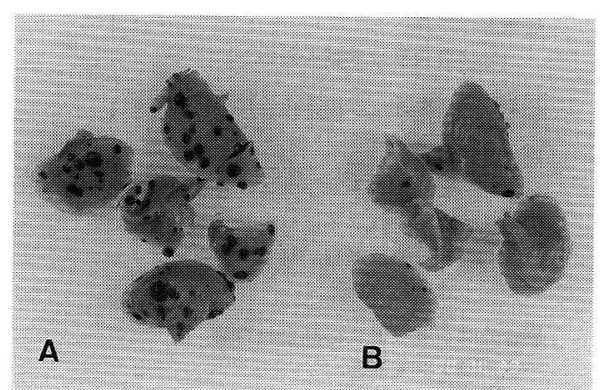

図 4.合成ポリペプチド, poly (RGD) によるマウス メラノーマ(B16-BL 6) の肺転移の抑制
A：対照群
B : poly (RGD) 投与群
黒点は腫瘤

表 $1 \mathrm{~A}$. 実験的肺転移に及ぼす合成ポリペプチドの効果

\begin{tabular}{|c|c|c|c|c|}
\hline 脡 痬 & ポリペプチド & 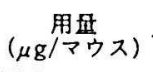 & $\frac{\text { 肺転移結節数 }}{\text { 平均 } \pm \mathrm{SD} \text { (籍国) }}$ & $\mathrm{P}$ \\
\hline B16-BL6 & PBS & - & $152 \pm 21(120 \sim 176)$ & \\
\hline \multirow[t]{4}{*}{ メラノーマ } & poly (RGD) & 500 & $38 \pm 5(33 \sim 46)$ & $<0.001$ \\
\hline & poly $(R, G, D)$ & 500 & $109 \pm 7(107 \sim 116)$ & \\
\hline & RGD & 3000 & $31 \pm 40(\quad 2 \sim 88)$ & $<0.001$ \\
\hline & & 500 & $123 \pm 22(98 \sim 158)$ & \\
\hline ルイス肺婳 & PBS & - & $191 \pm 56(117 \sim 262)$ & \\
\hline \multirow[t]{2}{*}{$(3 L L)$} & poly (RGD) & 500 & $51 \pm 18(23 \sim 65)$ & $<.0 .001$ \\
\hline & poly $(R, G, D)$ & 500 & $141 \pm 29(111 \sim 176)$ & \\
\hline コロン26 & PBS & - & $201 \pm 26(174 \sim 232)$ & \\
\hline \multirow[t]{2}{*}{ 結腸癌 } & poly (RGD) & 500 & $81 \pm 26(46 \sim 112)$ & $<0.001$ \\
\hline & poly $(R, G, D)$ & 500 & $204 \pm 32(169 \sim 250)$ & \\
\hline
\end{tabular}

種々の虞細胞をポリペプチドとともにマウスの尾静脈内より注射した後，14日 目に肺の転移結節数を計測した。

表 1 B．B16-BL6メラノーマの自然肺転移に及ばす合成ポリプチドの効果

\begin{tabular}{|c|c|c|c|c|c|}
\hline & ポリペプチド & 投与時期 & 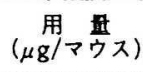 & $\frac{\text { 肺転移結節数 }}{\text { 平均士 } \mathrm{SD} \text { (䇥囲) }}$ & $P$ \\
\hline \multirow[t]{4}{*}{ 実験 I } & PBS & & - & $69 \pm 15(45 \sim 84)$ & \\
\hline & poly (RGD) & on day $7,9,11$ & $100 \times 7$ & $18 \pm 9(6 \sim 21)$ & $<0.001$ \\
\hline & poly $(R, G, D)$ & $13,15,17,19$ & $100 \times 7$ & $51 \pm 9(36 \sim 60)$ & \\
\hline & RGD & & $100 \times 7$ & $72 \pm 27(57 \sim 117)$ & \\
\hline \multirow[t]{2}{*}{ 実験 II } & PBS & on day $22,24,26$ & - & $106 \pm 23(i 3 \sim 122)$ & \\
\hline & poly (RGD) & $28,30,32,34$ & $100 \times 7$ & $41 \pm 19(26 \sim 73)$ & $<0.005$ \\
\hline
\end{tabular}

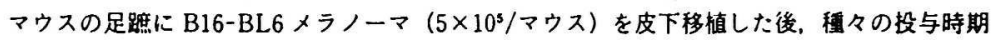
に $100 \mu \mathrm{g}$ のポリペプチドを尾静脈内に投与した。原発巣（腫湯）は移植後21日目に外科的に 切除し、さらに 2 週間後に肺の転移結節数を計測した。 
表 2. 合成ポリペプチド poly (RGD) の生物活性

\begin{tabular}{|c|c|}
\hline \multicolumn{2}{|l|}{ 合成ポリペプチド poly(RGD) の生物活性 } \\
\hline \multicolumn{2}{|l|}{ 癌転移抑制効果 } \\
\hline 実駿的肺転移（マウス癌細胞） & $: \downarrow$ \\
\hline （ヒト痁細胞） & $: \downarrow$ \\
\hline 自然肺転移 & $: \downarrow$ \\
\hline $\begin{array}{l}\text { 海細胞の浸潤 } \\
\quad \text { (基底膜再構成基質を用いた） }\end{array}$ & $: \downarrow$ \\
\hline 癌細胞の連動性（接触走化性） & $: \downarrow$ \\
\hline \multicolumn{2}{|l|}{ 痁細胞の接着 } \\
\hline $\begin{array}{c}\text { ・細胞外マトリックスに対する } \\
\text { (フィブロネクチン) }\end{array}$ & $: \downarrow$ \\
\hline ・血管内皮細胞に対する & $:-$ \\
\hline - 䀅細胞同士 & $:-$ \\
\hline \multicolumn{2}{|l|}{ 細胞外マトリックスの醉素的分解 } \\
\hline ヘパラナーゼ活性 & : - \\
\hline タイプIVコラゲナーゼ活性 & $:-$ \\
\hline \multicolumn{2}{|l|}{ 血小板凝集 } \\
\hline 癌細胞による & $: \downarrow$ \\
\hline ADP, コラーゲン,トロンビン刺激による & $: \downarrow$ \\
\hline 望櫁血管新生（マウス） & $: \downarrow$ \\
\hline 血管内皮細胞の遊走性 & $: \downarrow$ \\
\hline \multicolumn{2}{|l|}{ 免疫系細胞に及ぼす効果 } \\
\hline NK細胞・マクロファージ活性化 & $:-$ \\
\hline 炮細胞の分裂・增殖 & $:-$ \\
\hline
\end{tabular}

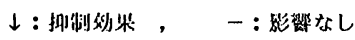

ついては表 2 に要約した。特に，(1) 癌細胞 B16-BL 6 メラノーマの肺へのアレスト（捕捉・ 着床)を有意に抑制する。(2) 血管内皮細胞への 着床に関わる癌細胞誘導性の血小板凝集を阻害 すること一一すなわち活性化血小板上の IIb/ IIIa レセプターへのフィブリノーゲン分子等の 結合を RGD 配列依存的に阻害する。(3) 基底膜 再構成基質を用いた癌細胞基底膜浸潤を抑制す る（表 3 ）。(4)癌細胞の移動能（接触走化性）や 癌細胞への血管内皮細胞の移動（すなわち微小 血管新生）を阻害する。(5) poly（RGD）の血中 の半減期は GRGDS ペプチドに比べ約 6 倍に 遅延している。

このように, poly（RGD）は癌転移形成の複 雑な過程において主として癌細胞膜上のレセプ ターとそのリガンドとの接着相互作用を抑制 し, 癌細胞の機能を制御するものと考えられる。 そのほか, 環状 RGDぺプチド, 組換え型フィ
表 3. 癌細胞浸潤に及ぼす合成ポリペプチドの効果

\begin{tabular}{lccl}
\hline \multirow{2}{*}{ ポリペプチド } & $\begin{array}{c}\text { 濃度 } \\
(\mu \mathrm{g} / \mathrm{m} l)\end{array}$ & $\begin{array}{c}\text { 浸潤した癌細胞数 } \\
\text { 平均 } \mathrm{SSD}\end{array}$ & $\mathrm{P}$ \\
\hline PBS & - & $136 \pm 19$ & \\
$\operatorname{poly}(\mathrm{RGD})$ & 20 & $172 \pm 34$ & \\
& 200 & $106 \pm 14$ & \\
& 500 & $58 \pm 17$ & $<0.001$ \\
$\operatorname{poly}(\mathrm{R}, \mathrm{G}, \mathrm{D})$ & 500 & $108 \pm 16$ & \\
$\mathrm{RGD}$ & 500 & $113 \pm 25$ & \\
\hline
\end{tabular}

B16-BL6 メラノーマ $\left(2 \times 10^{5}\right)$ は, トランスウェルチャン バーの上層に加えた。フィルターは上部表面をマトリジェル $(5 \mu \mathrm{g})$ で，下部表面はフィブロネクチン $(5 \mu \mathrm{g})$ で各々コー トした。実験開始後 6 時間目にフィルター下部表面へ移行し た癌細胞の数を計測した。

ブロネクチン・フラグメントあるいは (GRGDS) ${ }_{4}$ や GRGDS (GRGES) ${ }_{2}$ GRGDS ポリ マーを用いて癌の転移および浸潤抑制の試みも 行われている。一方, ICAM- 1 分子発現がメラ ノーマ細胞の進展・転移 $\left.{ }^{32}\right)$ と, LFA- 1 分子 $\left(\beta_{2}\right.$ インテグリン）の発現がある種のリンパ腫の肝 転移形成や線維芽細胞の単層への浸潤能と高い 相関を示す33)ことが報告された。化学発癌物質 MNNGにより誘発したヒトの悪性転換細胞は $\alpha_{6} \beta_{1}, \alpha_{2} \beta_{1}, \alpha_{1} \beta_{1}$ インテグリンの発現と浸潤能 が併行して増加したが， $\alpha_{5} \beta_{1} ， \alpha_{3} \beta_{1}$ の発現には 影響がみられず， $\alpha_{\mathrm{v}} \beta_{3}$ の発現はむしろ著しく低 下していることが示された ${ }^{34)}$ 。最近, Hemler ら ${ }^{35)}$ はVLA-2 cDNA を移入したヒト横紋筋 腫 $(\mathrm{RD})$ は $\alpha_{2}$ インテグリンの発現とコラーゲ ンやラミニンに対する接着性の上昇に加えて, ヌードマウスを用いた実験的および自然転移を 著しく増大することを報告している。また，七 トグリオーマ細胞の転移能の上昇は NCAM 蛋 白の発現消失と関係していること ${ }^{36)}$ や種々の七 卜肉腫細胞における $\mathrm{E}-$-カドへリンの発現の低 下や消失はその脱分化および浸潤能の上昇を引 起こすこと年なども見出されてきている。この 様にそれらの発現調節機構の解明も癌転移の制 御に寄与するかもしれない。細胞接着機構にお ける基礎的研究の進展とともに，細胞機能（接 着など）を制御する物質を用いた新しい癌治療 への応用が期待されるものと思われる。 


\section{文献}

1) Fidler, I. J. : Selection of succesive tumor lines for metastasis. Nature (New Biol.), 242 : 148149, 1973.

2 ) Poste, G. , Tzeng, J., Doll, J., et al. : Evolution of tumor cell heterogeneity during progressive growth of individual lung metastases. Proc. Natl. Acad. Sci. USA., 79 : 6574-6578, 1982.

3 ) Nakajima, M., Welch, D. R., Belloni, P. N. , et al. : Degradation of basement membrane type IV collagen and lung subendothelial matrix by rat mammary adenocarcinoma cell clones of differing metastatic potentials. Cancer Res., 47: 4869-4876, 1987.

4 ) Chadwick, D. E. , Lagrade, A. E. : Coincidental acquisition of growth autonomy and metastatic potential during the malignant transformation of factor- dependent CCL39 lung fibroblasts. J. Natl. Cancer Inst., 80 : 318-325, 1988.

5) Nicolson, G. L., Dulski, K. M. : Organ specificity of metastatic tumor colonization is related to organ- selective growth properties of malignant cell. Int. J. Cancer, 38 : 289-294, 1986.

6 ）竹市雅俊：組織構築の分子的基礎一細胞識別にお けるカドヘリンの役割一生化学, 59：1-9, 1987.

7 ) Springer, T. A.: Adhesion receptors of the immune system. Nature, 346: 425-434, 1990.

8 ) Hynes, R. O.: Integrins : a family of cell surface receptors. Cell, 48: 549-554, 1987.

9 ) Springer, T. A. and Lasky, L. A. : Sticky sugars for selectins. Nature, 349: 196-197, 1991.

10) Yamada, K. M. and Olden, K.: Fibronectinsadhesive glycoproteins of cell surface and blood. Nature, 275 : 179-184, 1978.

11) Plantefaber, L. C. and Hymes, R. O.: Changes in integrin receptors on oncogenically transformed cells. Cell, 56 : 281-290, 1989.

12) McCarthy, J. B., Furcht, L. T. : Laminin and fibronectin promote the haptotactic migration of B16 mouse melanoma cells in vitro. J. Cell Biol. , 98 : 1474-1480, 1984.

13) Wewer, U. M., Liotta, L. A., Jaye, M. et al. : Altered levels of laminin receptor mRNA in various human carcinoma cells that have different abilities to bind laminin. Proc. Natl. Acad. Sci. USA., 83 : 7137-7141, 1986.

14) Terranova, V. P., Williams, J. E., Liotta, L. A., et al. : Modulation of the metastatic activity of melanoma cells by laminin and fi- bronectin. Science, 226 : 982-985, 1984.

15) Pierschbacher, M. D., Ruoslahti, E.: Cell attachment activity of fibronectin can be duplicated by small synthetic fragments of the molecule. Nature, 309: 30-33, 1984.

16) Pytela, R., Pierschbacher, M. D., Rouslahti, E. : Identification and isolation of a $140 \mathrm{kd}$ cell surface glycoprotein with properties expected of a fibronectin receptor. Cell, 40: 191-198, 1985.

17) Humphries, M. J., Komoriya, A., Akiyama, S. $\mathrm{K}$. , et al. : Identification of two distinct regions of the type III connecting segment of human plasma fibronectin that promote cell type-specific adhesion. J. Biol. Chem. 262 : 6686-6892, 1987.

18) Elices, M. J., Osborn, L., Takada, Y., et al.: Cell, 60 : 577-584, 1990.

19) McCarthy, J. B. , Skubitz, A. P. N. , Zhao, Q., et al.: RGD-independent cell adhesion to the carboxy-terminal heparin-binding fragment of fibronectin involves heparin-dependest and independent activities. J. Cell Biol., 110 : 777787, 1990.

20) Akiyama, S. K., Yamada, S. S. and Yamada, K. M. : Analysis of the role of glycosylation of the human fibronectin receptor. J. Biol. Chem., 264 : 18011-18018, 1989.

21) Graf, J., Iwamoto, Y., Sasaki, M., et al.: Identification of an amino acid sequence in Laminin mediating cell attachment, chemotaxis, and receptor binding. Cell, 48:989-996, 1987.

22) Humphries, M. J., Olden, K., Yamada, K. M. : A synthetic peptide from fibronectin inhibits experimental metastasis of murine melanoma cells. Science, 233 : 467-470, 1986.

23) Iwamoto, Y., Robey, F. A., Graf, J., et al.: YIGSR, a synthetic laminin pentapeptide, inhibits experimental metastasis formation. Science, 238 : 1132-1134, 1987.

24) Saiki, I. , Iida, J. , Azuma, I. , et al. : Biological activities of synthetic polypeptides containing a repetitive core sequence (Arg-Gly-Asp) of cell adhesion molecules. Int. J. Biol. Macromol. , 11(2) : 23- 25, 1989.

25) Saiki, I. , Murata, J., Iida, et al. : The inhibition of murine lung metastasis by synthetic polypeptide, poly (Arg-Gly-Asp) and poly (Tyr-IleGly-Ser-Arg) with a core sequence of cell adhesion molecules. Br. J. Cancer, 59 : 194-197, 1989.

26) Murata, J., Saiki, I., Iida, J., et al. : Inhibition 
of tumor cell adhesion by anti-metastatic polypeptide containing a repetitive Arg-GlyAsp sequence. Int. J. Biol. Macromol., 11(4) : 226-232, 1989.

27) Saiki, I. , Iida, J. , Murata, J. , et al. : The inhibition of the metastases of murine malignant melanoma by synthetic polymeric peptides containing core sequences of cell-adhesive molecules. Cancer Res. , 49 : 3815-3822, 1989.

28) Murata, J., Saiki, I. , Azuma, I. , et al. : Inhibitory effect of a synthetic polypeptide, poly (Tyr-Ile-Gly-Ser-Arg), on the metastatic formation of malignant tumor cells. Int. J. Biol. Macromol., 11(4) : 97-99, 1989.

29) Saiki, I. , Murata, J. , Iida, J. , et al. : Antimetastatic effects of synthetic polypeptides containing repeated structures oa the cell adhesive Arg-Gly-Asp (RGD) and Tyr-Ile-Gly-Ser-Arg (YIGSR) sequences. Br. J. Cancer, $60: 722-728$, 1989.

30) Saiki, I. , Murata, J., Makabe, T., et al. : Inhibition of tumor angiogenesis by synthetic celladhesive polypeptide derived from fibronectin, poly (RGD). Jpn. J. Cancer Res. , 81: 668-675, 1990.

31) Saiki, I. , Murata, J., Matsuno, K. , et al. : Antimetastatic and anti-invasive effects of polymeric RGD peptide, poly (RGD) and its related analogues. Jpn. J. Cancer Res. ,81 : 660$667,1990$.

32) Johnson, J. P., Stade, B. G. , Holzmann, B. , et al. : De novo expression of intercellular-adhesion molecule 1 in melanoma correlates with increased risk of metastasis. Proc. Natl. Acad. Sci. USA., 86 : 641-644, 1989.

33) Roossien, F. F. , de Kuiper, P. E. , de Rijk, D. , et al. : Invasive and metastatic capacity of revertants of LFA-1-deficient mutant T-cell hybridomas. Cancer Res. , 50 : 3509-3513, 1990.

34) Dedhar, S. and Saulnier, R. : Alteration in integrin receptor expression on chemically transformed human cells : specific enhancement of laminin and collagen receptor complexes. J. Cell biol. , 110 : 481-489, 1990.

35) Chan, B. M. C., Matsuura, N., Takada, Y., et al. : In vitro and in vivo consequences of VLA2 expression on rhabdomyosarcoma cells. Science, $251: 600-1602,1991$.

36) Anderson, A. M. , Moran, N, Gaardsvoll, H. , et al. : Characterization of NCAM expression and function in BT $4 \mathrm{C}$ and BT $4 \mathrm{Cn}$ glioma cells. Int. J. Cancer, 47 : 124-129, 1991.

37) Frixen, U. H., Behrens, J., Sachs, M., et al. : E-cadherin-mediated cell adhesion prevents invasiveness of human carcinoma cells. J. Cell Biol. , 113 : 173-185, 1991. 